Canadian Journal of Higher Education

Revue canadienne d'enseignement supérieur

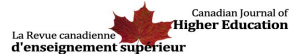

\title{
Book review of "Learning in the Age of Digital Reason"
}

\section{Jenn McArthur}

Volume 48, Number 2, 2018

URI: https://id.erudit.org/iderudit/1057112ar

DOI: https://doi.org/10.7202/1057112ar

See table of contents

Publisher(s)

Canadian Society for the Study of Higher Education

ISSN

2293-6602 (digital)

Explore this journal

Cite this review

McArthur, J. (2018). Review of [Book review of "Learning in the Age of Digital Reason"]. Canadian Journal of Higher Education / Revue canadienne

d'enseignement supérieur, 48(2), 192-193. https://doi.org/10.7202/1057112ar viewed online.

https://apropos.erudit.org/en/users/policy-on-use/ 


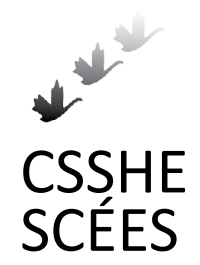

Canadian Journal of Higher Education Revue canadienne d'enseignement supérieur

Volume 48, No. 2, 2018, pages $192-193$

\section{Book Review / Compte rendu}

\section{Jandrić, Peter (2017). Learning in the Age of Digital Reason. Rotterdam: Sense Publishers. Pages: 406. Price: 49.99 CAD (paper).}

Reviewed by Jenn McArthur, Assistant Professor, Department of Architectural Science, Ryerson University.

In his introduction, Petar Jandrić expresses his desire to host the party of his dreams where he can engage with key thinkers on the topic of human learning in the age of digital reason. In this book, readers attend this virtual party and listen to dialogues with a broad spectrum of leading thinkers across five key disciplines: History and Philosophy (Larry Cuban, Andrew Feenberg, Michael Adrian Peters), Media Studies (Fred Turner, Richard Barbrook, McKenzie Wark), Education (Henry Giroux, Peter McLaren, Siân Bayne), Practice and Activism (Howard Rheingold, Astra Taylor, Marcell Mars and Tomizlav Medak), and the arts (Paul Levinson, Kathy Rae Huffman, Dmitry Vilensky). This is an impressive and diverse guest list. Unfortunately, due to this book's structure and because it is an extensive selection of previously-published individual interviews, only the host (and occasionally his co-author Ana Kuzmanić) speaks with the guests and the reader must observe these as discrete conversations rather than as a coherent whole.

While the introduction and afterword fall short of tying the conversations together, several significant unifying themes emerge. The influences of Ivan Illich and Paulo Freire are ever-present in the background of this book, and explicit in the majority of the dialogues; time and again, the dialogues remind the reader of the strong Marxist perspectives shared by Jandrić and many of his interviewees. Within this context, the themes of digital capitalism and consumerism in education are discussed in each book section, with the resulting discussions illuminating potential solutions presented by the open learning, deschooling, unschooling, and open publishing movements, as well as by the increasing potential (and need) for collaboration enabled by digital platforms. Similarly-and of significant value in the current discourse surrounding equity and diversity - the book returns to discussions of digital colonialism and post-colonialism, the need for the Internet to play a role as a public commons that is freely accessible to all and that represents a diversity of perspectives, and of the potential for self-learning as emancipation. On this note, it is beneficial that there is a moderate diversity of voices presented-three of the six- 
teen interviews are with women, and while contained within Europe (Scotland, England, and Jandrić's native Croatia) and post-colonial nations (Canada, US, Australia, and New Zealand), the geographically diverse perspectives speak both to the universal discourse supported by the digital age and its local variations. Of these, Canadian perspectives are very well represented in this book, notably Henry Giroux, Andrew Feenberg, Astra Taylor and-through the interview with Paul Levinson-Marshall McLuhan. For the Canadian scholar, while there is limited discussion of the Canadian context per se, it is refreshing to see such a high percentage of Canadian perspectives within an international compilation.

Sense Publishers' series «Educational Futures: Rethinking Theory and Practice» is designed to map out the field of educational futures through discourse on methods, future scenarios, and imagination narratives, and it focuses specifically on the context of globalization and the knowledge economy. As Volume 70 of this series, this book does not fit neatly within this description, but its contribution provides the range of perspectives Jandric wished to include to "create a document of our times - a snapshot of our reality, and the ways we experience that reality, at the moment here and now" (p. 361). As such, it is an extremely valuable reader for educators in 2018 wishing to understand the challenges, possibilities, and underlying influences of our digital age.

For practitioners, the interviews with Larry Cuban, Henry Giroux, Peter McLaren, Siân Bayne, and Astra Taylor are extremely valuable. The interview with Cuban opens the book with a discussion of unfulfilled promises of digital technology in the classroom: we had expected virtual classrooms by this point in history, but experience has demonstrated that access to technology doesn't correlate with effective use. Instead, Cuban argues that primarily physical classrooms with flipped and virtual elements enabled by technology will play a significant role in the foreseeable future, but that the long-awaited shift to virtual classrooms is unlikely. The discussion with Bayne later in the book complements this perspective; she discusses how the relationships and tensions between digital natives and digital immigrants (i.e., the older generation) are shaping our context, and expands the discussion of online learning to engage with issues of critical posthumanism and the anthropocene. McLaren and Giroux both engage with issues of emancipation through education but from dramatically different starting points. The conversation with Giroux evolves from a discussion of his insights from his work with racialized communities and engagement with cultural issues of post-colonialism to present a pedagogy of the precariat. In contrast, the discussion with McLaren starts with a position anchored in critical pedagogy and presents the need for information consciousness to promote change. Finally, providing the perspective of artist and activist, Taylor investigates the role of the student as a self-learner and the influence and potential of the unschooling movement in the network society as a strategy to fight against economic inequality.

As a set of individual chapters, this book forms an excellent resource for both scholars of education and for practitioners. The diversity of perspectives and range of discussions curated by Jandrić is exceptional and recommended reading. My key criticism of this book is the lack of coherent narrative between these conversations; while this work can be likened to a patchwork quilt, there is potential to create an extraordinary tapestry of ideas. 